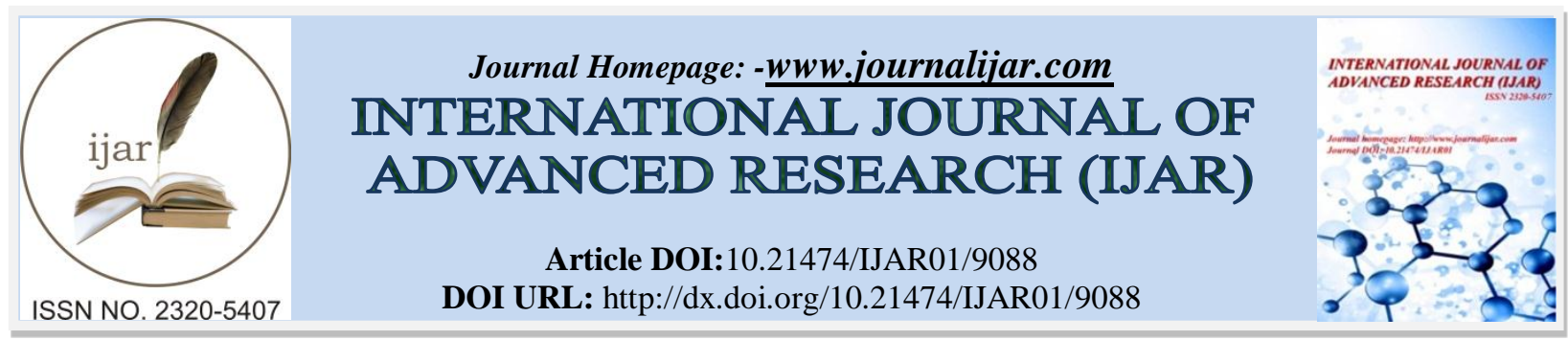

RESEARCH ARTICLE

\title{
THE EVALUATION UPON THE AWARENESS DEVELOPMENT OF STATE DEFEND AMONG THE SOCIETY IN TANGERANG CITY.
}

Tahan Samuel, Lumban Toruan and Priyanto.

Permanent Lecturer at The Indonesian Defense University-Bogor.

\section{Manuscript Info}

Manuscript History

Received: 16 March 2019

Final Accepted: 18 April 2019

Published: May 2019

Key words:-

evaluation, CIPP model, state defense, national defense.

\begin{abstract}
This research aimed to evaluate the implementation of awareness development of state defend in Tangerang city in order to achieve the target of nation defense strategy. The method applied in this research is qualitative method, particularly CIPP (context, input, process, product) evaluation model to evaluate component of context, input, process, and product used in the means to build the awareness on state defend. The source of this study are teachers, college students, high school students, members of mass and youth organization, non-governmental organization, public figure, religious leaders, and cultural figure. Besides, state officials such as in national unity, politics, and community protection agency as well as staff in district and sub-district in Tangerang city also acted as the object awareness development activity on state defend in Tangerang city. The data were also collected from Directorate of Defense Strategy Ministry of Defense, representative office of Defense Ministry in Banten Province, and Regional Army Unit acted as the executor of the state defend awareness development in Tangerang city. The primary data were collected through interview, questionnaire, and observation, while the secondary data were acquired from documentation study. The findings presented that the implementation of state defend development in order to achieve one of the strategic targets of state defense were only executed under the title of "fair" which was affected the level of state defense awareness of the component of the society in Tangerang.
\end{abstract}

Copy Right, IJAR, 2019,. All rights reserved.

\section{Introduction:-}

Tangerang city is one of the inseparable parts from the capital city of the Republic of Indonesia which is on a level with the municipality. As one of the supportive regions of the capital city with a population of 2.093 .706 people (Statistics central body of the Tangerang City, 2016), it does not only gain the strategic position, but also receives both positive and negative impact from the dynamic life occurs in the national capital city, Jakarta. Many cases regarding social life happening in Tangerang such as criminality, lack of togetherness and environmental awareness, are considered to be affected by the capital city lifestyle. For instance, the rate of criminality in Tangerang city increases by year. Lately, there are many disturbances upon the peace and order in society, such as stealing, robbery (especially for motor vehicle and other means of things) which often leads to violence committed by the criminal to the victim. Based on the report on type of burglary case committed in 2017, the cases reported were 83 cases and 
increased to 114 cases in 2018. Similarly, the case of severe assault reported in 2017 was about 50 cased and increased to 55 cases in 2018. While, fraud/deception cases reported in 2017 were 35 cased and increased to 38 cases in 2018. For occupational fraud, there were 8 cases and significantly elevated to 20 cases in 2018 (Tangerang Metro Resort Police, 2018).

Furthermore, in every joint-event between The Indonesian National Armed Forces member and society, either for physical and non-physical activities, in Civic Mission Operation such as The Indonesian National Armed Forces Team-up to Build Villages (Indonesian Army-Territorial General Staff, 2009), it seemed that the society who participated tend to be the middle to low class society, but almost none of the middle-to high class society appeared in the event. This situation showed that togetherness and sense of belonging in participating in such activities (regardless knowing that it is conducted for the sake of their environment), has been kind of lost among the middle to high class of society. (Tangerang 0506/Military District Command, 2017). Not only that, there are some people in Tangerang who still stand against the "Five Principle's / Pancasila" as the national ideology, though the number is relatively small but it is enough to pose insecurities among the societies. (Tangerang 0506/Military District Command, 2018).

As seen from all the case examples above, it can be seen that all the issues basically related to the awareness of state defend among the society. For example, criminality issues are relevant to the state defend awareness on the attitude of "the ability to create a safe, peaceful, and clean environment" as well as "prioritizing communal importance than personal matters" (The Indonesian of Ministry of Defence-Directorate of Potential Defense,2014). In regards to the issues of 'lack of participation to environmental activity' is relevant to state defend awareness which is reflected in the attitude on "harmonious and cooperation in people's lives". Furthermore, in respect to the case of anti "Five principle's / Pancasila" is also relevant to the state defend awareness among society which is reflected in the attitude of believe in "Five principle's / Pancasila" as the ideology of the nation. (The Indonesian of Ministry of DefenceDirectorate of Potential Defense,2014).

What is "State Defend?" State defend is the attitude, behaviour, and action of the citizen that is encouraged by their loyalty to The Unitary State of the Republic of Indonesia in accordance to Pancasila and Constitution of the Republic of Indonesia 1945 in ensuring the sustainability of the country and the nation (The Indonesian of Ministry of Defence, 2017). While state defend awareness is the non-physical power which is, eternally, the willingness to devote and sacrifice as the means of dedication, proportionally, between the profession and the interests of state defense. (The Indonesian of Ministry of Defence, 2015). Development the state defend awareness among Indonesia citizen is one of the 5 (five) targets of state defense strategy (The Indonesian of Ministry of Defence, 2015). In order to achieve the strategic targets above, one of the ways is by "development the awareness and the ability of state defense" (The Indonesian of Ministry of Defence, 2015).

In respect to the goal of creating Indonesian citizens who have the adequate state defend awareness, it is required to conduct a training by the related authorities. Surely, Indonesian citizen here refers to the whole citizen of Indonesia, including those domiciled in Tangerang city, as the supportive city to the capital city of the Republic of Indonesia. State defend awareness development is any means of attempts, actions, and activities conducted to provide knowledge and build the attitude and behaviour of a citizen who devote to the nation, aware of the nation and state, loyal to Pancasila as the nation's ideology, willing to sacrifice for the state and nation, as well as has the initial capacity of state defend both psychologically and physically in order to maintain the sustainability of the nation and country (The Indonesian of Ministry of Defence, ,2017).

Originally, the policy to conduct a training to create citizen with a good state defend awareness has long been implemented in region of this country, including Tangerang city. In response to the fact, the question would be "how far does the state defend awareness development successfully carry out by the related authorities in Tangerang city so far?"

If the state defends awareness development went smoothly, the disturbance or obstacles in the cases mentioned above should not have happened, or at least being reduced minimally. Therefore, it seems logical when such question like "how far does the state defend awareness development successfully create state defend awareness citizens as one of the strategic targets of state defense in Tangerang city? In order to answer the question, it is necessary to evaluate the implementation of state defend awareness development conducted in Tangerang city, particularly in Banten Province region, as one of the supportive cities to the capital city of Indonesia. 
According to James C. Mc David et. al (2005) evaluation can be considered as a structural process to process and synthesize information in order to reduce the level of inaccuracy for the stakeholder about a certain program or policy that is being enacted. Furthermore, he added that evaluation aims at answering questions or hypothesis test in which the answer will be combined with basic information in the program or policy that is being enacted. Song and Nick Letch (2012) stated that evaluation is the process used to identify, measure, and assess the value of an object in a certain context.

Therefore, evaluation on the attempt to create a state defend awareness citizen as one of the targets of strategic defense plays an important and urgent role that it is urgently need to gain empirical data about how far the attempt has been successfully achieved, especially in Tangerang city. The empirical data will be one of the references to the decision making in fixing the program. Besides, this evaluation is also carried out to gain the empirical data about the value and the quality of the state defense awareness among the society.

\section{Theoretical Framework}

The model of evaluation is varying, since there are many types of them. Some of them are quite popular to be used as the strategy or framework in conducting a program evaluation. Though one model might be different from the others, but they have the same core as all of them meant to collect data and information regarding to the evaluated object, and the goal is to provide materials for the decision maker about the continuation of a program (Suharsimi Arikunto \& Cepi Safruddin Abdul Jabar, 2008). There are various evaluation model generated by the experts, and each of them have both its strengths and weaknesses. In other words, nothing is better than the others. The models only work as the tool which helps the evaluator in collecting the relevant information or data regarding the evaluated object.

From all the various evaluation model, the model used in this research is the one developed by Daniel L. Stufflebeam and Anthony J. Shinkfield (2007) that is known as "CIPP Evaluation Model". The reason why the researcher choose CIPP evaluation model is because this model is a thorough framework of guidance in running a program, project, institution, and system. CIPP evaluation model is one of evaluation models which try to provide information for a decision with systematic workflow. Not only that, CIPP evaluation model is practical, easy to understood and done, as well as able to provide information about the success or a failure of a program quickly.

Thus, CIPP evaluation model is considered very relevant and suitable to evaluate the attempt to create state defend awareness citizen as one of the strategic targets of defense in Tangerang city, Banten Province in order to make some decisions and recommendations in improving the state defend awareness in Banten Province include Tangerang City.

CIPP model consists of five types of evaluation, those are: Context, Input, Process and Product Evaluation. Each of the types is explained as follows (Wirawan (2011):

Context Evaluation. According to Daniel Stufflebeam, context evaluation is meant to answer the question of: What needs to be done? This evaluation identifies and assesses the needs which becomes the foundation of why an activity is formed. (Wirawan (2011)

In respect to this research, the focus of context evaluation is about how far the "goals and targets" of state defend awareness are compatible with the needs of state defense strategy. Then, context evaluation will also evaluate whether the goals and targets established are suitable with the conditions of the citizen. Finally, is the goals of state defend awareness evaluation have been specified clearly or not clear?

Input Evaluation. It aims to find out the answer of: What should be done? It identifies the problem, asset, and opportunity to assist the decision maker to define the goals and priorities. Besides, evaluation also help the communities to assess the goals, priorities, and benefits of the program, assess the alternative approach, action planning, staff planning, and budgeting for the feasibility and potential of cost effectiveness in fulfilling the targeted needs and goals. The decision makers use input evaluation to select among the available plans, compose the budget proposal, position the staff, schedule the work, assess the activity plan, and set the budgeting (Wirawan (2011)

In regards to this research, the focus of input evaluation is to evaluate how far the "action planning, strategy, procedure and organization structure, resource support (human, facilities, budget), monitoring, and control" are able 
to support the process to achieve the goals and targets established in creating the state defend awareness citizens in Tangerang city of Banten Province.

Process Evaluation. Process evaluation aims at answering the question: Is it being done? This evaluation attempts to access the implementation of a plan in order to help the program staff to execute the activities and help broader stakeholders to assess the program and interpret the benefit (Wirawan (2011).

In respect to this research, the focus of evaluation process is to evaluate how far "the action planning, strategy, procedure and organization structure, resources support (human, facility, budget), monitoring, and control" has been carried out to create state defend aware citizens in Tangerang Province, Banten Province. Aside of that, the obstacles found during the implementation will also be evaluated in order to create state defend awareness citizens at Tangerang City in Banten Province.

Product Evaluation. Product evaluation is meant to find the answer of: Was it successful? It tries to identify and access the output from the benefit, both planned and unplanned benefit, or in a short term and long-term effect. Both could assist the staff to stay focus on how to reach the most essential benefit that it could also help broader stakeholder to gain the targeted needs (Wirawan (2011).

In regards to this research, the focus of product evaluation is to evaluate the result of "whether the implementation of the activity manage to achieve the goals and targets" as what it is planned to improve the state defend awareness. Furthermore, this evaluation will also provide the input of "whether any of the unexpected results appear in the activity is worth to be continued, repeated, or even extended to other situations. Besides, this product evaluation will also identify the weaknesses from the activity of state defend awareness development as the means to achieve strategic target of state defense in Banten Province include Tangerang City.

\section{Research Methodology: -}

This research was conducted in 2018 and only in the region of Tangerang city. In other words, South Tangerang City and Tangerang Districts is out of the scope of this research. The research method used a qualitative method with an evaluation of the CIPP model. The data were collected through documentation process of written data, interview, observation, questionnaire and focus group discussion (FGD). During the data collection process, the researcher did a direct interview with the data sources in order to gain the required information.

The interviewee involved as the subject in Tangerang city are as follows:

1. Policy Maker and the Person in Charge of State Defend Awareness Development, that is the Directorate of Defence Strategy, Ministry of Defence of the Republic of Indonesia, particularly the Director of State Defence and the Head of Defence Ministry Representative Office of Banten Province in Serang city and Tangerang city;

2. The executor of State Defend Awareness Development, those are: National Unity and Politics Agency, Local Government of Tangerang, and the Head of Regional Army Unit (Tangerang 0506/Military District Command) and other related institutions, Head and Staff of District Office, as well as Head and Staff of Sub-District Office come from several sub-districts and villages such as Benda; Batuceper; Karang Anyar; Karang Sari; and Batu Jaya.

3. The participants of awareness development of state defend are several teachers and students from senior high school, the representative of students from college, the member of mass organization and youth of Tangerang city, the social institution of Tangerang city, public figures, religious figure and cultural figures as well the society come from sub-districts and villages such as Benda, Batu Ceper, Karang Anyar, Karang Sari, and Batu Jaya.

The activity of observation is done in order to compare and find out the facts in real life with the data from the documentation in the research location. The data analysis technique that is used in evaluating the implementation of awareness development of state defend of the society of Tangerang city is the data analysis by using the descriptive statistics using the model developed by Matthew B. Miles and A. Michael Huberman (1994) which covers: (a) data collection, (b) data reduction, (c) data display, (d) Conclusion drawing/verification.

According to the descriptive definition and the meaning for the evaluation, it set the criteria of evaluation that is used as the parameter of the implementation of creating society with awareness of state defend in Tangerang city. These criteria will be the standard parameter to measure achievability of the implementation which are the phases of 
evaluation (context, input, process, and product). While the aspects that are evaluated in every component with the criteria of evaluation that are expected are as follows.

1. The criteria of Context Evaluation are that the goal formulation is clear, realistic, contributive, achievable as well as has gone through the scoring process of need analysis and the result of evaluation of the previous program. Then, the target formulation of the activity is clear, realistic, significant, measurable, achievable, and contributive.

2. The criteria of Input evaluation are :1) The planning of activity is detailed, relevant, achievable, specific, 2) The procedure of implementation is clear, detailed, effective, and relevant, 3) The structure of organization for the implementation of activity is realistic, clear, effective, and specific, 4) The support of human resources is relevant, contributive, specific in term of quality and quantity, 5) The Support of facility and infrastructure are relevant, contributive, specific in term of quality and quantity, 6) The Support for budgeting is relevant, contributive, the budget allocation that supports the implementation of the activity according to the State Defense, and 7) The monitoring and control of program implementation is effective, relevant, contributive and specific.

3. The criteria of Process Evaluation are : 1) The implementation of planning of the activity is done according to the target, significant and realistic; 2) The procedure and mechanism is done accordingly and contributive; 3 ) The structure of organization is done effectively and contributive; 4) The human resources has been provided effectively and is contributive; 5) The facility and infrastructure has been provided effectively and is contributive; 7) Monitoring and controlling system is done effectively and is contributive.

4. The criteria of Product Evaluation are: there are increase of awareness of state defend of the society in the region of Tangerang after the evaluation phase is done.

For the qualitative analysis, then the criteria are transferred and composed to be the score according to the grading system. For the purpose of evaluation which uses the qualitative criteria, it is composed by using the criteria with no consideration. It means that it calculates the many indicators in the component that can fulfill the requirement. The indicators for the answers are divided into three categories, those are: "Yes I have", "No I have not", and "I don't know". For the percentage of scoring scale, the maximum score is set at $100 \%$ and the minimum is at $1 \%$ with the three categories of: (1) "Good" percentage is from 70\% to $100 \%$, (2) "Fair" percentage is from $30 \%$ to $69.9 \%$, and (3) "Inadequate" percentage is from $1 \%$ to $29.9 \%$.

\section{Discussion: -}

The discussion of this research is to find out how the implementation of awareness development of state defend that is done by the stakeholders related to the Tangerang city, those are: Head of Representative Office of Ministry of Defense in the region of Banten Province cooperating with the Office of National Unity, Politics, and Community Protection Agency along with the District Military Command of 0506/Tangerang upon the society of Tangerang City (the representative of students from college, teachers, mass organization, and NGOs) as well as religious, cultural and public figures, local government officials that conduct and experience the impact of the awareness development through the CIPP evaluation model with the result of the following.

\section{Aspect of Context (Planning)}

The analysis upon the answers of the object and the subject of awareness development of state defend are classified into six groups consisting of college students, students, teachers, mass organization, and NGOs, religious figures, cultural figures, public figures, society, and local governmental officials related to "planning aspects" that is "stakeholders related to the implementation of awareness development of state defend" has explained "what are the goals and targets" of the planning of awareness development of state defend for the society. Besides, "related stakeholders" have also gained the inputs from the object of the awareness development of state defend in term of "what are the goals and targets" related to planning of awareness development of state defend so that they can create the awareness of state defend on the Tangerang City region.

The results show varied answers saying that the implementation is done with the score of "good", "fair", and "inadequate". From six grades of data sources, two opinion gave the answer of "good", three of them gave the "fair" answer, and the last one gave "inadequate" as the answer. If it is seen from the result holistically, the evaluation from the aspect of context can be classified as "fair" is on the highest rank compared to the answer of "good" and "inadequate". Which means that generally, the conclusion that the "planning aspect" of awareness development of state defend of the society of Tangerang City is implemented "fairly well". With the "fair" result, obviously it will affect the next evaluation that is the input (preparation) aspect. 


\section{Aspect of Input (Preparation)}

The analysis upon the answer of the object and subject of awareness development of state defend related to the "preparation aspect" that is that "related stakeholders of awareness development of state defend" have explained about how the planning of implementation, organizing of activity, support of human resources in implementation, support of facility and infrastructure of the implementation of activity; support of budgeting for the implementation, and the control for the activity of awareness development of state defend to the society.

The results show varied answers, that the implementation is "good", "fair", "inadequate". From the level of data sources that give the opinion of it to be done in the level of "good" is one opinion, four of the argued that it is "fair", and one opinion that mention it is 'inadequate'.

Holistically, the result of the evaluation for the preparation aspect for the awareness development of state defend of the society of Tangerang City region is dominated by those who argued that the score is "fair". Thus, the preparation for awareness development of state defend of the society of Tangerang City region is implemented fairly, which obviously if combined with the score of the planning aspect will affect the evaluation for the next point of process evaluation (implementation).

\section{Aspect of Process (Implementation)}

The analysis upon the answers from the objects and subjects of awareness development of state defend in relation to "aspect of implementation" is that "the stakeholders related to the implementation of awareness development of state defend" has conducted the awareness development based on the: planning and organizing the activity, the support of human resources, facility and infrastructure, as well as the support of funding for the activity, and also control system for the implementation of awareness development of state defend to the society.

The result showed the answers of "good" and "fair" only, while the "inadequate" answer was not chosen. From the six levels of data sources, one opinion mentioned that the answer is "good", while the other five opinions were giving the answers of "fair", hence no opinion stating the answer of "inadequate".

Holistically, the result for the evaluation in the aspect of process (implementation) of awareness development of state defend of the society of Tangerang City region has been dominated with the result of "fair". Which means, the preparation for awareness development of state defend of Tangerang City region is "fairly done". With the evaluation result, the aspect of process (implementation) that is very dominant in the category of "fair" and combined with the result of evaluation of planning mentioned previously will surely affect the next evaluation that is the aspect of product (result).

\section{Aspect of Product (Result)}

The analysis upon the answers from the objects and subjects of awareness development of state defend related to the "aspect of result" is whether the "stakeholders related to the implementation of awareness development of state defend" has been successfully improve the nationalism (reflected in the attitude of loving the local product, loving the environment and able to conduct the clean and healthy living); whether or not the conduct is successful in increasing the awareness of living character of nation and state (reflected in the attitude of respecting other society, united with the other society in living, prioritize the public interests above personal and group's interests); whether it has successfully increasing the faith upon Pancasila as the ideology of the State (reflected in the attitude of following the duty of religion and faith well and properly; the awareness in helping others in the society); as well as whether it is successfully increase the early capacity of Defending the State.

The result showed the answers of "good" and "fair" only, while the answer of "inadequate" was not chosen. From six levels of data sources, one of the opinions chose the answer of "good", while the other five opinions were choosing the answer of "fair", thus the answer of "inadequate" was not chosen. Holistically, the evaluation on the aspect of product (result) of awareness development of state defend of society of Tangerang City region is heavily dominated by the answers of "fair". It means that the very dominant answers of "fair" is affected by the evaluation of planning, preparation as well as the evaluation of implementation mentioned earlier. Thus, it is understandable that the degree of awareness of state defend in the Tangerang City is still "not very high" because obviously the awareness development of state defend is only implemented "fairly". 


\section{Conclusion and Suggestion: - \\ Conclusion}

Referring to the discussion of the result of research mentioned above with the implementation of awareness development of state defend of the society of Tangerang City that is done by the related stakeholders, some conclusions can be drawn as follow.

Based on the evaluation of each components

1. The aspect of planning of awareness development of state defend of the society of Tangerang City was implemented in the level of "fair". However, there are some noted that is the lacking of preparation done or only a few activities of awareness development of state defend that are prepared.

2. The aspect of preparation of awareness development of state defend of the society of Tangerang City was implemented in the level "fair",

3. The aspect of process (implementation) of awareness development of state defend of the society of Tangerang City was implemented in the level of "fair", also

4. The aspect of product (result) of awareness development of state defend of the society of Tangerang City by the related stakeholders has achieve the level score of "fair". This achievement is obviously inseparable from the aspect of planning, preparation that is previously mentioned that will definitely affect the aspect of product (result).

Of course, referring to the result of the evaluation mentioned above will affect as well to the degree of awareness of state defend of the components of the society in Tangerang City. Hence, it is understandable to see the score of awareness development of state defend is in the level of "fair" or "Not very high".

That is why, the activity of awareness development of state defend of the society in Tangerang city still requires the continuation so that the degree of awareness development of state defend of the society can get higher.

1. Then, this result of research is expected to give contribution to the development of management study especially those related to the evaluation of a policy or continuous program that involves the element of mass society.

2. However, in the implementation of this research is still facing the limitation in collecting the data related to the size of location for the research, the limitation of knowledge of the respondents and related to the context of research, as well as the interest and the understanding and the urgency from the score of the research.

3. That is why, improvement is needed to be continued to find out how the awareness development of state defend of the society of Tangerang City region with the different evaluation model to gain data from the different perspectives.

\section{Suggestion}

Based on the conclusion mentioned above, then several points of suggestions can be given to improve the implementation of awareness development of state defend of the society of Tangerang City region is in the following.

The program of awareness development of state defends of the society of Tangerang City region that has been done still can be continued with the activities that should be done that are:

1. Perfecting the planning of activity of awareness development especially those related to the explanation that is broader and more intensive related to the "goal" and "target" of activity that is conducted as well as digging more of the inputs from the society about what ought to be the goal and target of activity that will be conducted. Besides, more plans needed to be done for the awareness development of state defend in Tangerang City.

2. Perfecting and improving the preparation for the implementation of the activity awareness development of state defend especially those related to the things that support the implementation of activity such as organizing activity, support of human's resources, support of facility and infrastructure, support of budgeting, and control system for the activity;

3. Perfecting and improving the implementation of activity of awareness development as well as eliminating the limitation and the weakness through the process of awareness development such as the explanation that is broader and more massive in term of what is the "goal" of the activity done and what is the "target" of activity done, enlarging the number of input from the society about how the activity of awareness development of state defend that is expected by the society as well as fulfilling the supports that are necessary for the proper continuation of the activity of awareness development. Besides, it is also necessary to enlarge the number of activities of awareness development of state defend by involving the participants from the component of the society in more ways in following the activities of awareness development of State Defense. 
4. The continuation of research is needed to be done to find out how the awareness development of state defend in Tangerang City region that use the evaluation model that is different to gain result from different perspectives.

\section{References: -}

1. Arikunto, Suharsimi dan Cepi Safruddin Abdul Jabar (2008). Evaluation of Educationnel Programs: Practice Theoretical Guidelines for Students and Educational Practitioners. Jakarta: PT.Bumi Aksara.

2. David, James C.Mc dan Hawthorn, Laura R.L. (2005). Key Concepts And Issues In Program Evaluation And Performance Measurement. Chapter 1, London: Sage Publications, Inc.

3. Indonesian Army-Territorial General Staff (2009). Program Organizer Handbook of The Indonesian National Armed Forces Team-up to Build Villages (TMMD) Jakarta: Indonesian Army-Territorial General Staff. $\begin{array}{llccc}\text { 4. Tangerang } & \text { Military } & \text { District } & \text { Military } \\ \text { Tangerang Territorial Guidelines for } & 2017 \text { Period: Tangerang 0506/ Military District Military. }\end{array}$

5. Tangerang 0506/ Military District Military

Tangerang Territorial Guidelines for 2018 Period: Tangerang 0506/ Military District Military.

6. Tangerang Metro Resort Police (2017). Data Recapitulation of Types of Cases in 2017, Tangerang : Tangerang Metro Resort Police.

7. Tangerang Metro Resort Police, (2018). Data Recapitulation of Types of Cases in 2018,Tangerang: Tangerang Metro Resort Police.

8. The Indonesian of Ministry of Defense, Indonesian Defense Policy White Paper. Jakarta; The Indonesian of Ministry of Defense.

9. The Indonesian of Ministry of (2017). Guidelines for Developing State Defend Awareness in Campus: Introduction Activities for New Students, Jakarta: The Indonesian of Ministry of Defense-Directorate of Potential Defense.

10. Miles, Mattew B dan A. Michael Huberman (1994). Qualitative Data Analysis, New Delhi: Sage Publications.

11. Song, Nick Letch (2012). "Research on IT/IS Evaluation: A 25 Year Review Xingchen". Electronic Journal Information Sistem Evaluation. Volume 15 Issue 3.

12. Statistics Central Body of The Tangerang City (2016), Population of Tangerang City, 2005-2016, Tangerang.

13. Stufflebeam, Daniel L dan Shinkfield, Anthony J (2007). Evaluation Theory, Models \& Applications. San Franscisco: Jossey Bass.

14. Wirawan (2011). Evaluation: Theory, Models, Standards, Applications and Professionals. Jakarta: PT. Rajagrafindo Persada. 